\title{
Paleostress Analysis in Brittle Structures of the Camaquã Copper Mines
}

\author{
Maurício Guerreiro Martinho dos Santos ${ }^{1 *}$, Renato Paes de Almeida ${ }^{2}$, \\ Antonio Romalino Santos Fragoso-Cesar ${ }^{3}$
}

\begin{abstract}
Fault planes with striae and kinematic indicators from the Camaquã Copper Mines, Caçapava do Sul (Brazil), were analyzed through graphical methods and structural geology software in order to determine the stressfield orientation for the numerous tectonic events that affected the region, and in this way determine the paleostress fields. 94 faults with slickenside striae and kinematic indicators were acquired and interpreted in the field, and with the Tensor software. The relative chronology of the events was obtained through cross-cutting relationships of multiple overprinting fault striae, and stratigraphical analysis according to previous published papers. Field data was integrated through geographical information systems (GIS) for correlation with data obtained through remote sensing and imagery processing. We identified four distinct paleostress fields: ENE to NE extension (Cretaceous); NNE to N-S compression (Triassic); NW extension (Paleozoic); and WNW compression (Cambrian). A specific study was applied to the mineralized brittle structures, leading to the proposition of a model for the emplacement of the ore bodies of the Camaquã Copper Mines. This model is characterized by the opening and filling of fractures that were parallel to the maximum horizontal stress-field, resembling T-fracture structures, during the main deformational transcurrent event that affected the Camaquã Basin $~ 530 \mathrm{Ma}$.
\end{abstract}

Keywords: structural geology; paleostress analysis; Camaquã Basin; Minas do Camaquã; mineralization control; Copper.

Resumo Análise de Paleotensões em Estruturas Rúpteis das Minas de Cobre do Camaquã. Planos de falhas com estrias e indicadores de movimento encontrados nas Minas do Camaquã, Município de Caçapava do Sul (RS, Brasil), foram analisados por meio de métodos gráficos e softwares de geologia estrutural para a determinação das orientações dos campos de esforços envolvidos nos diversos eventos tectônicos que afetaram a região, obtendo-se, assim, os paleocampos de tensões. Foram adquiridos 94 dados de falhas com estrias e indicadores cinemáticos que foram interpretados em campo e pelo software Tensor. A cronologia relativa dos eventos foi determinada por relações de cortes entre estrias em planos de falha e análise estratigráfica, embasada em trabalhos regionais disponíveis na literatura. Os dados de campo foram integrados por meio de sistemas de informação geográfica para correlação com dados obtidos via sensoriamento remoto e processamento de imagens. Foram identificados quatro paleocampos de tensão distintos: distensão ENE a NE (Cretáceo); compressão NNE a N-S (Triássico); distensão NW (Paleozoico); compressão WNW (Cambriano). Um estudo específico envolvendo exclusivamente as estruturas rúpteis mineralizadas levou à proposição de um modelo de mineralização para as Minas do Camaquã. Esse modelo compreende um sistema de abertura e preenchimento de fraturas paralelas ao esforço horizontal máximo, semelhante a fraturas tipo-T, durante o evento de deformação transcorrente principal que afetou a Bacia do Camaquã em $~ 530$ Ma.

Palavras-chave: geologia estrutural; análise de paleotensões; Bacia do Camaquã; Minas do Camaquã; controle de mineralização; Cobre.

INTRODUCTION The region of Minas do Camaquã has a long history related to different events of tectonic deformation, and is regionally characterized as an intersection of two major shear zones. The present study aims to bring relevant results to the knowledge evolution about the tectonic events that acted in the Camaquã Basin and surrounding areas, and to discuss the relationship between tectonics and the emplacement of the copper deposits of the region. Through the analysis of brittle structures, the different tectonic events that acted in the Camaquã Basin (Neoproterozoic-Cambrian) are analyzed and chronologically classified, particularly the one related to the copper mineralization.

The large number of structures exposed in the pits of the Camaquã Copper Mines enabled a

${ }^{1}$ Programa de Pós-Graduação em Geoquímica e Geotectônica, Instituto de Geociências, Universidade de São Paulo - USP. São Paulo (SP), Brasil. E-mail: mauriciogmsantos@gmail.com

${ }^{2}$ Departamento de Geologia Sedimentar e Ambiental, Instituto de Geociências, Universidade de São Paulo - USP, São Paulo (SP), Brasil. E-mail: rpalmeid@usp.br

${ }^{3}$ Departamento de Geologia Sedimentar e Ambiental, Instituto de Geociências, Universidade de São Paulo - USP, São Paulo (SP), Brasil. E-mail: romalino@usp.br

*Corresponding author 
comprehensive structural analysis. Structural data were collected and interpreted in the field by means of methods for kinematics determination (Angelier 1994) and subsequently analyzed through paleostress analysis methods (according to the World Stress Map criteria). We used the Tensor software for processing data of structural geology (Delvaux \& Sperner 2003) in order to distinguish and determine the orientation of stresses of the different deformation events that affected the area, thus obtaining the regional fields of paleostress. Field data were also integrated to a geographic information system (GIS) for correlation with regional lineaments obtained via remote sensing, which allowed the characterization of the regional kinematics for the main regional deformation event.

The reconstitution of paleostress fields was integrated to the determination of the relative chronology of events, which was made by observing the cross-cutting relationships of multiple overprinting fault striae, stratigraphic relations obtained in the field, and through stratigraphic analysis based on the deformation events described in previous studies (Almeida 2005, Almeida et al. 2012). In this way, we obtained a chronological framework of the tectonic events responsible for the tectonic history of the region. Through the separated analysis of the mineralized structures data, we propose an age and model for the emplacement of the ore bodies.

\section{Geological context The Camaquã Copper Mines} were the target of the first records of copper exploitations in Brazil during the mid-19th century. Its ore accumulations occur in brittle deformation structures, which are very common in the sedimentary rocks of the region. These sedimentary units are part of to the Camaquã Basin, sedimentary basin related to the stages of stabilization of Gondwana (Almeida 1969). The basin was filled by siliciclastic and volcaniclastic rocks of Neoproterozoic to Eopaleozoic age which were deposited in rift systems developed subsequently to the Brasiliano orogenic event (Fragoso-Cesar et al. 2000a, 2000b and 2001, Almeida 2005, Almeida et al., 2009, 2010). Its occurrences are controlled by NNE faults, and the basin is divided into three sub-basins by two regional highs (Fig. 1).

The rocks of the Camaquã Supergroup (Fragoso-Cesar et al. 2003) record important events that were subsequent to the metamorphism of the Brasiliano Orogeny, offering a rich chronologic framework of the events that affected the region afterwards. The here studied unit is related by Fambrini (2003) to the Santa Bárbara Group, which crops in the three sub-basins, with occurrences in structural windows under the Guaritas Group in the Camaquã Central Sub-basin, the study area. Fambrini (2003) and Fambrini et al. $(2005,2007)$ interpreted these rocks as conglomerates related to preserved alluvial and deltaic fan deposits, as well as conglomerates related to preserved braided rivers deposits, and sandstones and rhythmites interpreted as preserved deposits of tidal flats and distal ephemeral river systems.

Since the mid-19th century, several studies have addressed the copper occurrences in the region of Minas do Camaquã and its associated geological units. However, the main advances in the understanding of the stratigraphic stacking of the Camaquã Basin occurred only in the 1960s. The sandstones and conglomerates of the region were related as part of the Santa Barbara Formation by Robertson (1966), while Ribeiro et al. (1966) classified it in the Arroio dos Nobres Formation (composed by Mangueirão and Vargas Members). Ribeiro (1978) divided the lithotypes from the mines into five levels, mappable in a 1:25,000 scale - Lower Sandstone, Lower Conglomerate, Intermediate Sandstone, Upper Conglomerate, and Upper Sandstone.

Bettencourt (1972) observed that the rocks of the region occur at the core of an anticline formed by rocks of the Camaquã Group and determine a monocline with layers of $\mathrm{NE}$ direction. Interpreting the dominant structural feature as one large transcurrent fault system of NE direction with associated NW normal faults, this author related such structures with the copper mineralization; he also observed post-mineralization faults that cut through the structures aforementioned, proposing a main vertical stress, a traction component of NE/SW directions, and a mean NW/SE compression component. Thus, Bettencourt (1972) related the NE faults presenting dextral strike-slip components to the Irapuá Fault System (sensu Ribeiro et al. 1966), as the result of a first order regional stress. Afterwards, Bettencourt \& Damasceno (1974) related the copper ore to the NW fractures of sinistral kinematics with SW and NE dips, thus interpreting that these accumulations had occurred under a transtractive regimen.

Silva Filho (1997) described an anastomosed pattern of fractures of WNW to NW trends in the region, identifying five groups of faults: 


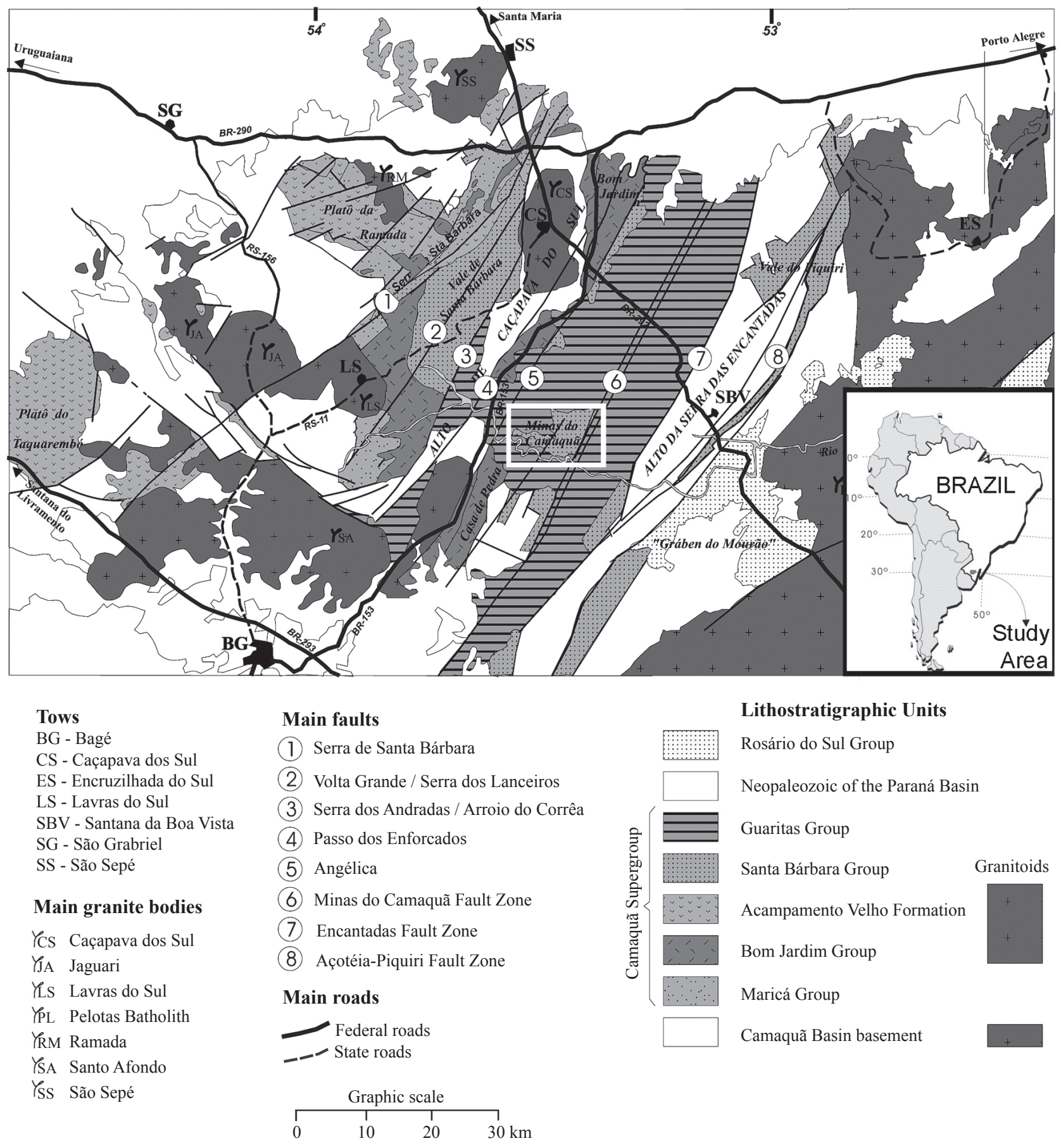

Figure 1 - Schematic map of the Camaquã Supergroup, in the Central-South portion of Rio Grande do Sul. The studied region is indicated by the white chart. Adapted from: Santos et al. (1978), Fragoso-Cesar et al. (2000) and Almeida (2005).

(1) sinistral NW trend, (2) normal NW trend, (3) dextral W-NW trend; (4) normal W-NW trend, (5) dextral, normal and reverse N-NE trend. In this way, this author interpreted a stress field related to an E to E-SE compression and a N to N-NE extension, also describing a NW trend sinistral fault system compatible with a set of synthetic Riedell fractures, that would have originated the transcurrent duplexes. According to this author, the N-NE trend fractures are secondary and synthetic.

The Santa Bárbara Formation sensu Robertson (1996) was re-classified as a Group by Fambrini (1998) based on studies of the exposures in the Camaquã Central Sub-Basin, region of Minas do Camaquã. According to Fambrini (1998), these siliciclastic rocks are Ediacaran in age, intensely tilted 
and fractured, and were affected by many regional tectonic events. Recent studies (e.g. Almeida 2005, Almeida et al. 2010, 2012) reveal a complex history of deformation in the basin, with recurring events of brittle deformation related to the main cycles of subsidence and uplifting of the Camaquã Basin. According to Almeida et al. $(2010,2012)$, the main post-deformational event that affected the Camaquã Supergroup was characterized by an intense strike-slip faulting, mainly NE-SW to NNW-SSE sinistral faults, and ENE-WSW to WNW-ESE dextral faults, including major faults that juxtapose different units of the Camaquã Supergroup and its basement. New methods for structural analysis currently allow a more complete identification of the events that affected the basin, integrating them with models of regional tectonic evolution for the Ediacaran and the Cambrian.

\section{METHODOLOGY}

Method history Several definitions of stress ratios are found in literature (e.g. Bott 1959, Carey-Gailhardis $\&$ Mercier 1987, Angelier 1994). The study of paleostress fields came up in the 1970s, when researchers realized the possibility to reconstruct the stress fields responsible for the formation of brittle structures through the analysis of fault families presenting striations and kinematic indicators, thus developing graphic methods that enable determining the stress orientations. In this way, Angelier \& Mechler (1977) developed the right dihedral method for the reconstruction of paleostress fields through graphic analysis of striated faults data through stereographic projection, determining compressive and extensional dihedral.

Delvaux \& Sperner (2003) demonstrated that the sense of slip and direction of displacement in a fault can be deducted through the examination of slickenline striae, which provides data - containing fault strike and dip, striae orientation and block kinematics - whose inversion provides the relationship between the main stress fields ( $\sigma 1, \sigma 2$ and $\sigma 3)$, and the stress ratio $(\mathrm{R})$, in which $\mathrm{R}=(\sigma 2-\sigma 3) /(\sigma 1-\sigma 3)$.

Data acquisition We collected data on 94 faults with slickenside striae and kinematic indicators exposed in structures of the Camaquã Copper Mines. The rocks typically present little weathering and well-preserved structures, an ideal situation for such kind of study. In order to determine faults' displacement direction, we adopted the criteria proposed by Petit
(1987), Angelier (1994) and Doblas (1998). The slickenside striae kinematics were analyzed according to methods proposed by Angelier (1994). For each fault with slickenside striae, we computed: (i) fault plane dip direction, (ii) dip amount, (iii) rake, (iv) striae direction, (v) fault kinematics, (vi) type of kinematic indicator, and (vii) rate referring to the quality of the measured data.

For the extraction of regional lineaments, a Principal Component Analysis (Crósta 1992) was applied to an ASTER image, with the first Principal Component being used to extract ground texture information. Digital terrain shading obtained through the digital elevation model (DEM) was applied to this image, in order to highlight the main structural features.

Structural data processing The Tensor software was used for structural data processing and paleostress analysis (Delvaux \& Sperner 2003). For the analysis of structures, we considered as faults only the planes presenting measurable slickenside striae and reliable kinematic indication, encompassing all other types of brittle planes generically as fractures. Through the identification of these relations, we inferred the stress fields that were responsible for each structure, and modeled the possible offsets on each fault plane. Only fault-families with a minimum of four striated faults were used for paleostress field determination. The interpreted ages for each event were based on the dates obtained through different methods, in various studies previously conducted on the Camaquã Basin, and regarding the cut-relationships of slickenside striae in a same fault plane. The chronologic framework of the tectonic events was obtained from Almeida et al. (2012).

LITHOTYPES The lithologies found in the Camaquã Copper Mines are listed below:

- Stratified-conglomerate and stratified-sandstone arranged in 20 to $60 \mathrm{~cm}$-thick, tabular to lenticular sets with flat base and slightly convex top, presenting pebbles and isolated boulders overlapping on the A-B plane. The stratification is determined by pebble concentration. Provenance is characterized by granites, aplites, rhyolites, and intraformational mudclasts. Carbonate cement is common, and more evident in the coarser levels;

- coarse-sandstone with incipient stratification, in up to $40 \mathrm{~cm}$-thick levels, and presenting granules and small pebbles. Intercalated with the stratified-conglomerate facies in rhythmic successions; 
- medium- and fine-laminated sandstone up to $30 \mathrm{~cm}$-thick, arranged in isolated lenses that alternate with the conglomeratic facies and coarse-grained sandstones with incipient stratification. Isolated granules are rare, and parting-lineation can be locally observed;

- rare, discontinuous levels of greenish siltstone, few centimeters thick, intercalated with the sandy and conglomeratic facies;

- stratified coarse-sandstone similar to those described above, but with evident stratification and with no association with the conglomeratic facies. These sandstones present granules and sparse pebbles, and occur in decimetric, tabular or lenticular layers with flat bases and slightly convex top, alternated with tabular and trough cross-stratified sandstone facies, with sharp contacts;

- medium- to coarse-sandstones presenting scattered pebbles, in isolated or amalgamated series, arranged in decimetric lenticular layers of flat or concave base and convex top. The dominant sedimentary structure is medium-scale cross-stratification;

- Fine- to medium-sandstone with plane-parallel lamination, well-sorted, micaceous, and presenting intraformational mudclasts. Occur in tabular layers about $30 \mathrm{~cm}$-thick, intercalating with laminated siltstone facies.

- Dark-brown, laminated-siltstones, in layers 2 to $6 \mathrm{~cm}$ thick, locally presenting mudcracks, laterally continuous for several meters.

Figure 2 shows the above described lithotypes in a stratigraphic log obtained the Uruguay pit.

STRUCTURAL ANALYSIS Analysis of orbital imagery (Figure 3 ) revealed the predominance of NNE lineaments and, secondarily, WNW lineaments, indicating significant deformation events that resulted in the regional prevailing structures on the region. The expression of NNE and WNW lineaments is pronounced by ridges and valleys with such directions. The Camaquã Copper Mines complex is located on a structural-high with WNW direction, in the truncation of this with the topographic expression of the NNE lineaments. The location of the mines can be defined as the truncation between the two major regional shear zones. The WNW orientation of the Uruguay and Piritas pits follows the main orientation of the mineralized

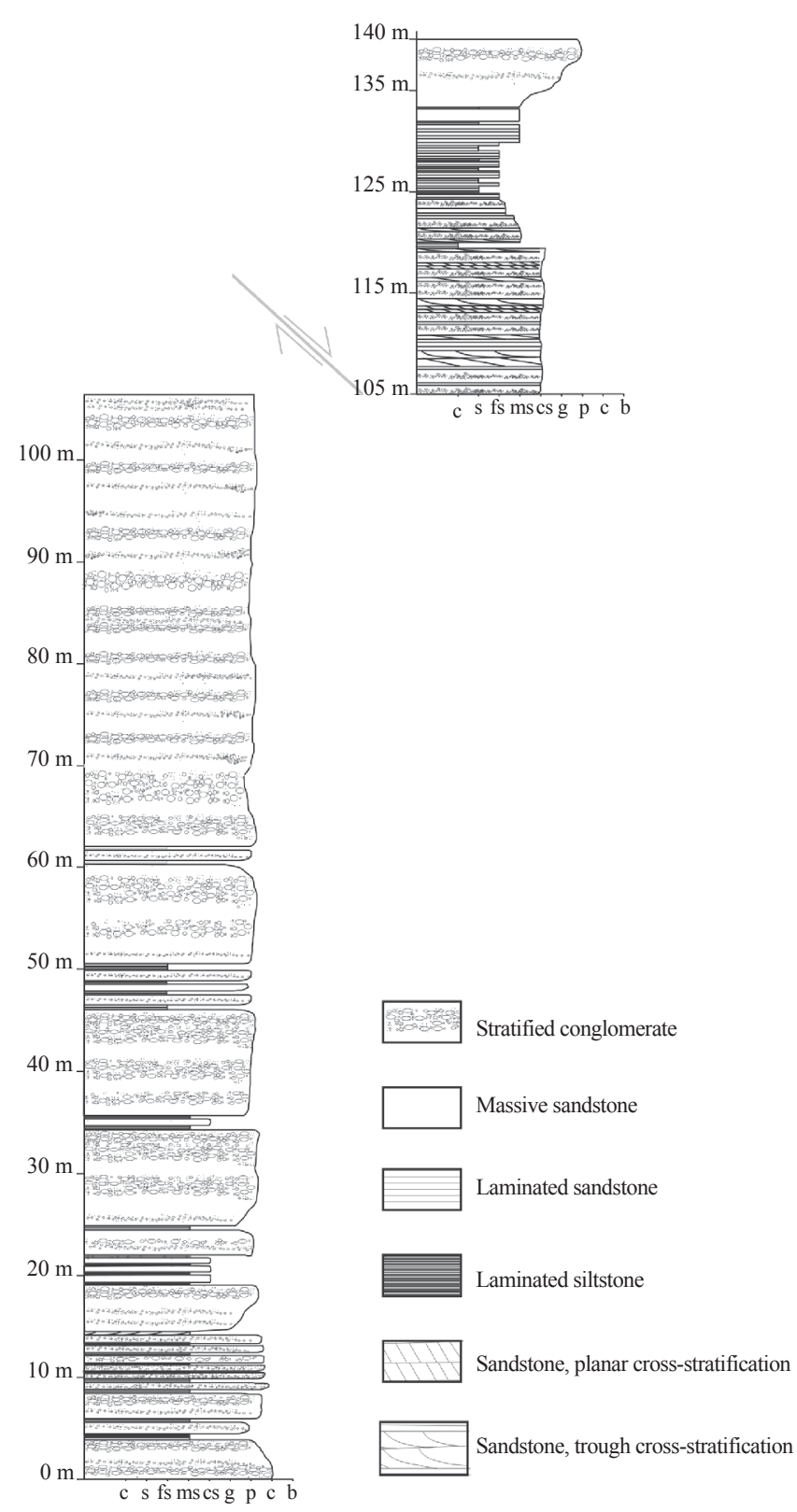

Figure 2 - Stratigraphic log of the Camaquã Copper Mines in the Uruguay pit. The section is trunked by normal fault.

structures. In a local scale, three main lineament directions were distinguished: the most important two are, in fact, those of WNW and NNE direction, with the NW lineaments occurring in a lower frequency. The mine is cut by these directions.

The rocks of the Camaquã Copper Mines are intensely fractured and faulted, presenting a significant feature of a flower-structure fault, suggesting that pervasive transcurrent systems have affected the region (Fig. 4). Several fault planes present more than one generation of slickenside striae, cross-cutting relations of which revealed in the field the chronology of the events (Fig. 5). 

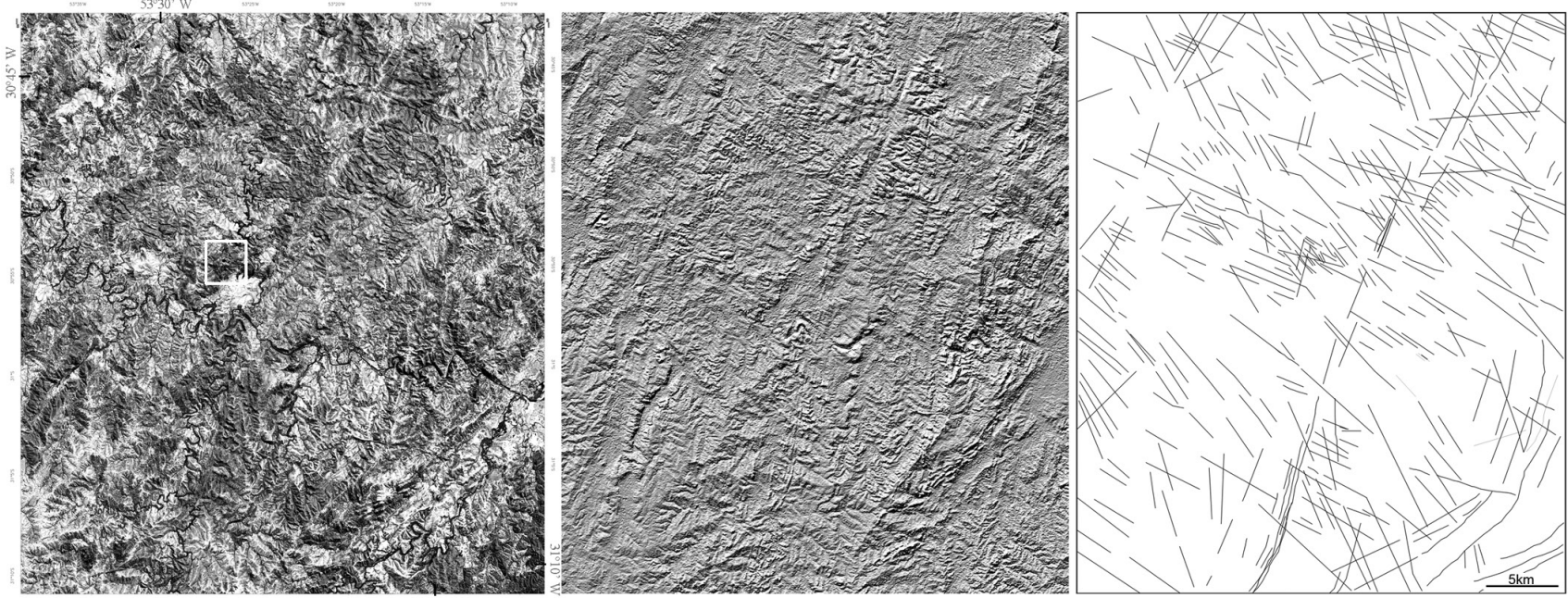

Figure 3 - Left - ASTER imaging (PC1) of Caçapava do Sul; the region of Minas do Camaquã is highlighted by the white polygon. Center - digital terrain shading ( $345^{\circ}$ azimuth, $30^{\circ}$ elevation) made by digital model of elevation in the ASTER image. Right - interpretation of main regional lineaments based on both previous images.
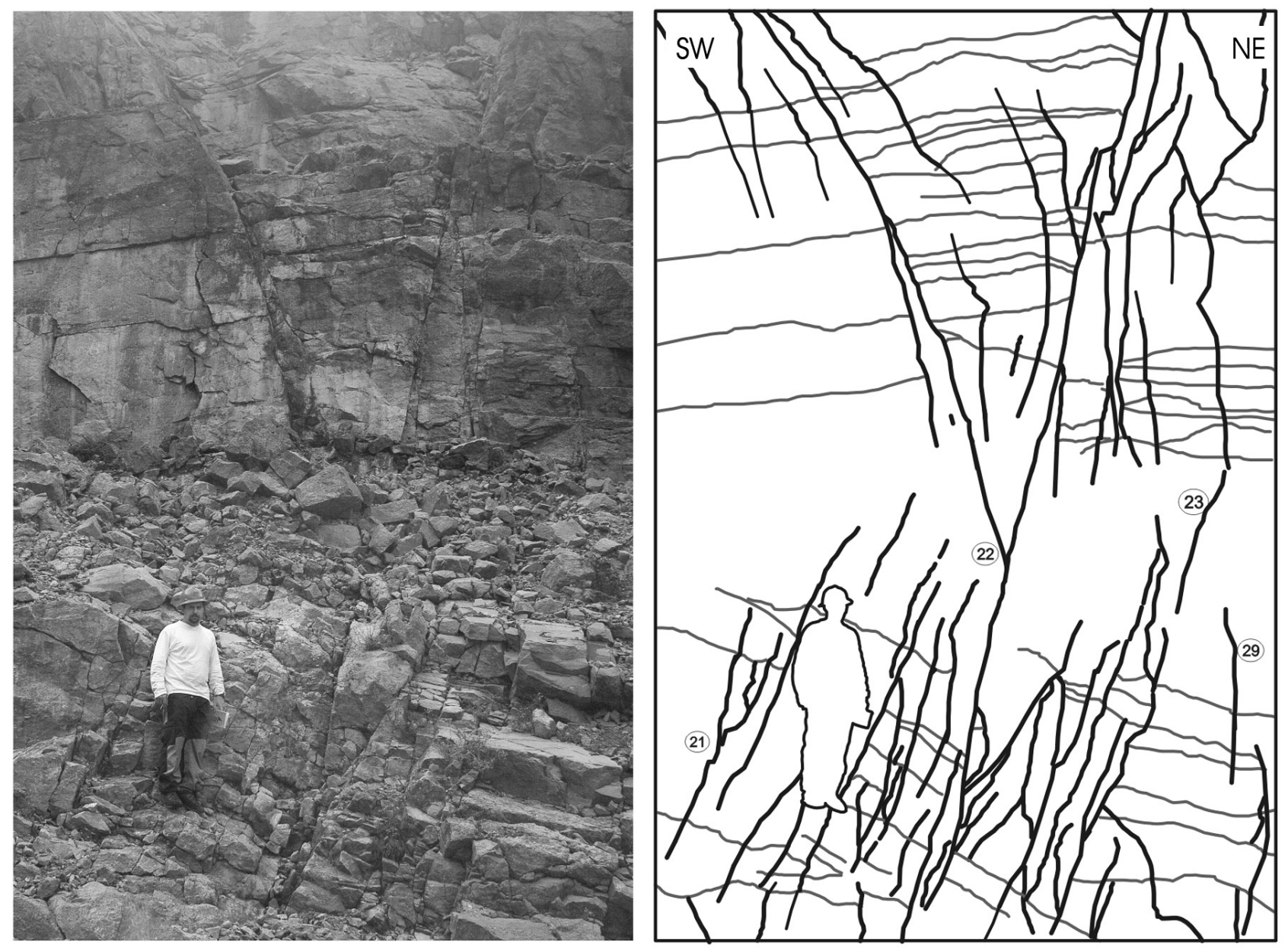

Figure 4 - Negative flower-structure fault in the Piritas pit, with noted structural measures: 21) 230/65; 22) $023 / 68$; 23) $032 / 55$; 29) $225 / 75$. Set and coset limits represented in gray lines; fractures represented in black lines. Scale $-1.65 \mathrm{~m}$. The negative flower-structure fault suggests the transtractive model proposed by Bettencourt \& Damasceno (1974). 

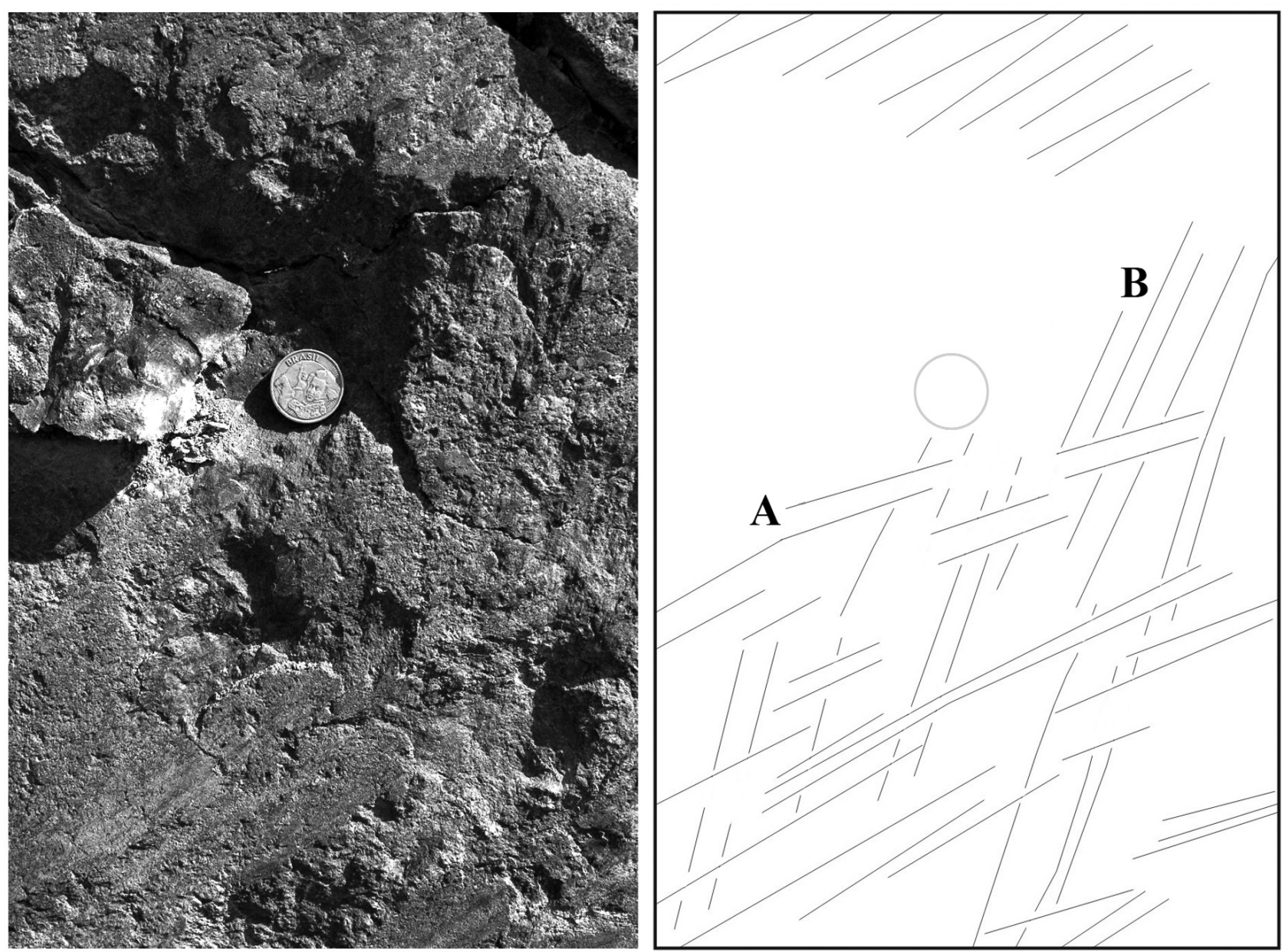

Figure 5 - Cut relationships of slickenside striae: stria A (006/61//25 R D DS 2) cutting stria B (006/61//60 $R N D S$ 1). (Data: direction of dip/ dip // rake, kinematics, type of kinematic indicator and quality of data). Currency for scale $-R \$ 0,10$ (cents).

Joints and faults presenting striated fault planes filled with mineral concentration of calcite, pyrite, bornite, hematite, quartz, and malachite were observed, mostly of which are concentrated in structures with NW-SE to WNW-ESE direction. Mineralization is structurally controlled, appearing in fault planes, in tension-fractures (T-Fracture) fill, and in brecciate zones which are parallel to the fault planes. T-fracture structures point a major horizontal stress field with a NW direction (Fig. 6).

The data analysis revealed the absence of a single stress field which is consistent with all the observed structures, indicating multiple events of brittle deformation throughout the geological history of the region. Four distinct stress fields were identified: (1) ENE to NE extension (Figs. 7A and 7B), (2) NW extension (Fig. 7C), (3) WNW compression (Fig. 7D), (4) NNE to N-S compression (Figs. 7E and F).
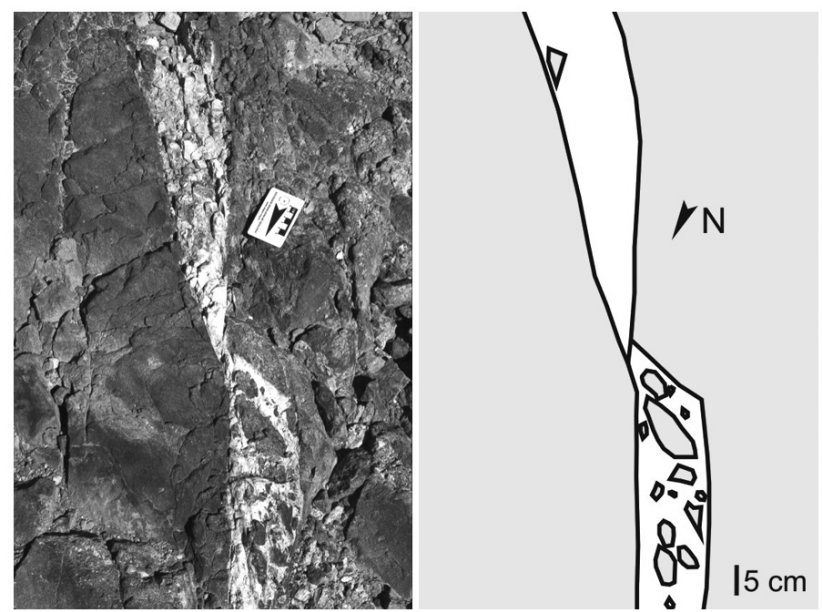

Figure 6-T-type fracture found in the Uruguay pit. The structure is parallel to the main stress direction (NW-trend). 


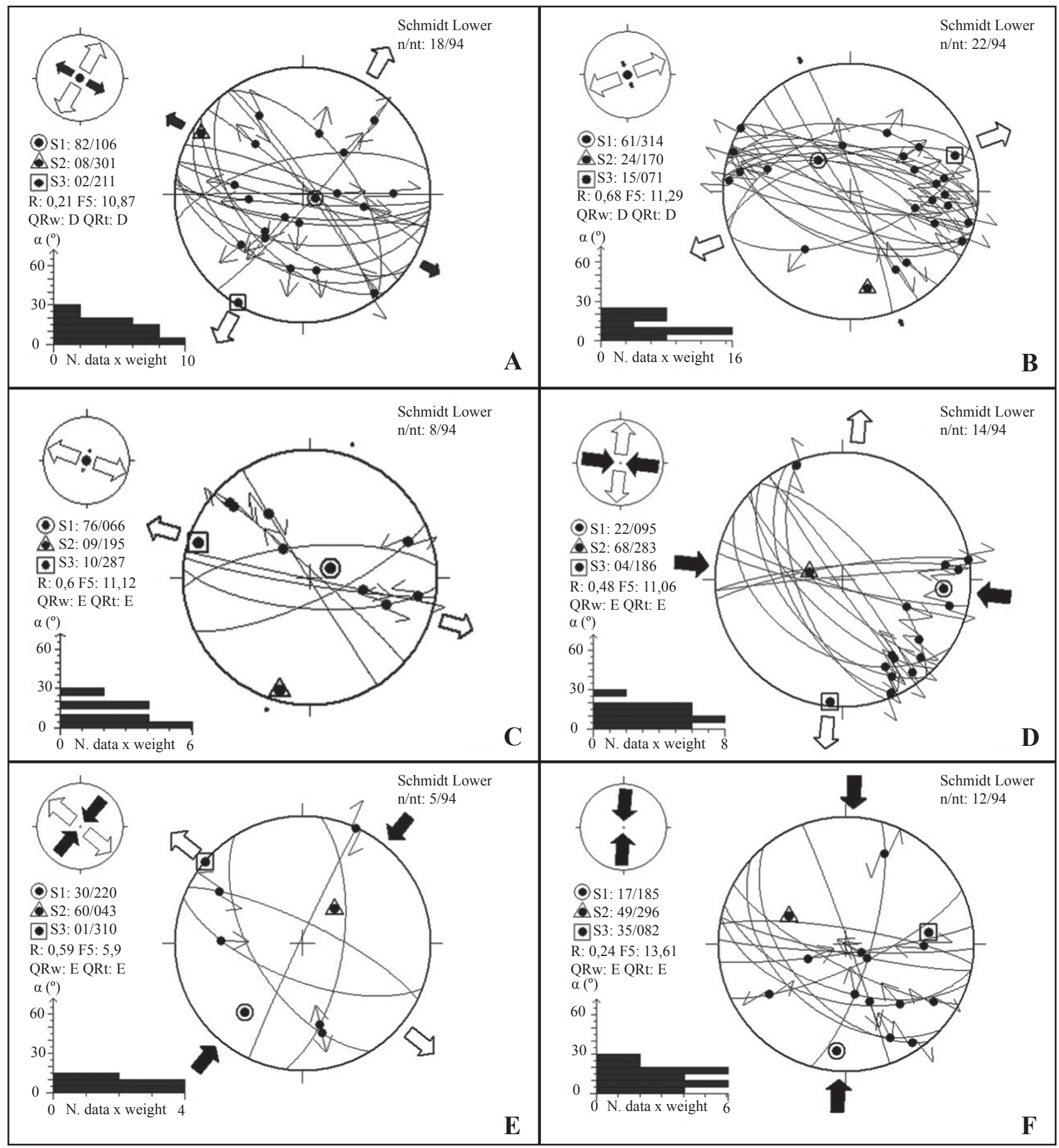

Figure 7 - Stereographic projections (lower hemisphere) of faults with slickenside striae and kinematic indication. Groups established through paleostress analysis, presenting the orientation of the stress fields in each group. A) NE distension; B) ENE distension; C) NW distension; D) WNW compression; E) NE compression; F) NNE compression.

The mineralized structures were separately analyzed aiming at the chronological correlation with the regional events and characterization of its paleostress field (Fig. 8). The main kinematics of such features is interpreted as a dextral WNW and ENE structures, normal/oblique, dextral faults with NNE dips, as well as associated NW sinistral faults. Paleostress analysis revealed a transcurrent field of NW compression, with nearly vertical $\sigma 3$.

DISCUSSION The here identified WNW compression event was also recognized by Almeida (2005) and Almeida et al. (2012) in successions of the Guaritas Group, being interpreted as Eopaleozoic in age once 


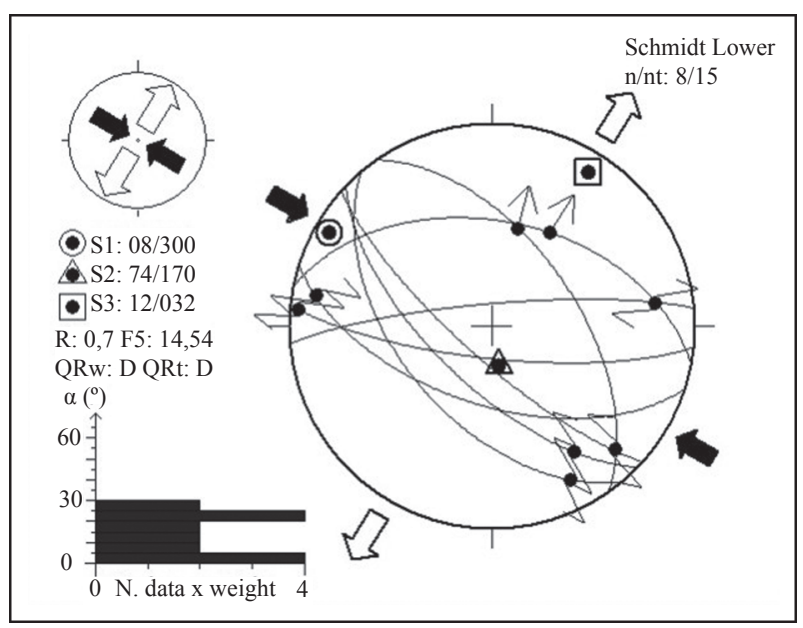

Figure 8 - Stereographic projections (lower hemisphere) of mineralized faults presenting slickenside striae, with indication of movement and respective paleostress fields indicated.

it affects the Intrusive Suite Rodeio Velho (535 Ma Almeida 2005) and does not affect any younger Phanerozoic unit. The correlation with the compressive events in the African mobile belts led Almeida (2005) to suggest an age of around $530 \mathrm{Ma}$ for this event. The main deformation found in the Camaquã Basin was characterized by Almeida (2005) and Almeida et al. (2012) as the result of a NW compression which, in the region of the Camaquã Mines, may be related to structures with indication of a WNW maximum horizontal stress. A rotation of structures by a N-S transcurrent sinistral binary might have resulted in this change of direction due to the continuous and intense deformation as a result of the NW compression (Fig. 9).

Separated analysis of the mineralized structures revealed that these structures are related to the WNW compression event, in structures mainly parallel to the major stress axis. The copper mineralization is thus interpreted as related to the tectonic event of WNW compression, with migration of mineralizing fluids in sets of joints and faults that currently present a WNW-ESE trend (due to the above described sinistral rotation), which possibly behaved as extensional structures (Santos 2007, 2010), consistent with the T-fracture of the Riedel conjugate system. Taking the proposed timeline for the events recognized and the suggested ages for each event by previous workers, we can infer that the mineralization of the Camaquã Copper Mines was emplaced in the host rock during the deformation event which was interpreted by Almeida (2005) as approximately 530 Ma. Further studies are necessary to

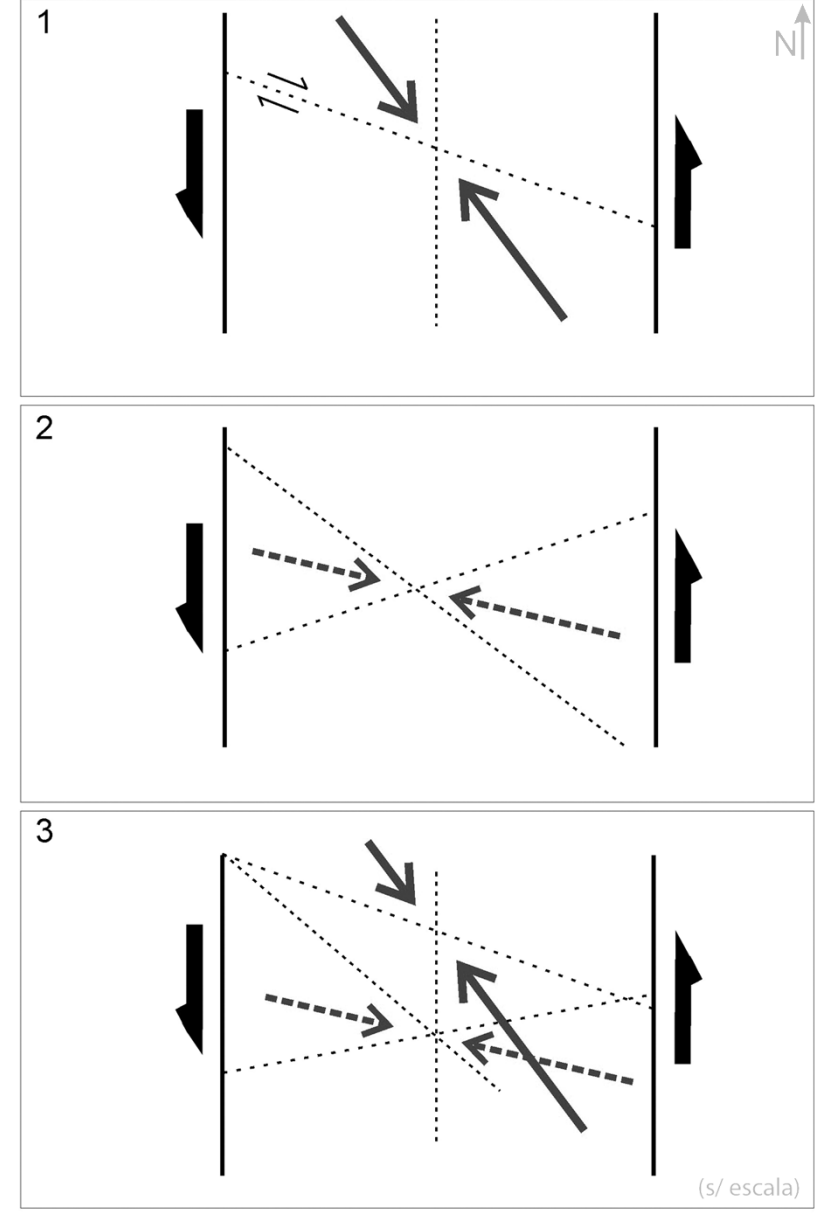

Figure 9 - Representation of structures' overlapping generated in one single event through sinistral transcurrent binary rotation.

investigate the relationship of this event of mineralization with the Guaritas Group.

The NW extension has no direct interpretation, since similar stress-fields have been previously recognized only as a basin-forming tectonic event (Almeida 2005), a hypothesis that is contradicted by the slickenside striae cut relationships (Santos 2007). Furthermore, these slickenside striae cross-cut relationships suggest that the NW extension event is older than the NNE to N-S compression, thus situated between the Triassic and the WNW compression of $530 \mathrm{Ma}$.

It is possible to infer through striae cross-cutting relationship that the NNE to N-S compressive deformation and the NW extension occurred after the compression $530 \mathrm{Ma}$, that is, after the main depositional events of the Camaquã Basin, which occurred between the Ediacaran and the Cambrian periods. In this way, it is possible to correlate the $\mathrm{N}-\mathrm{S}$ compression with the stress fields identified in Triassic successions in the region (Almeida 2005, Tomba 2006). 


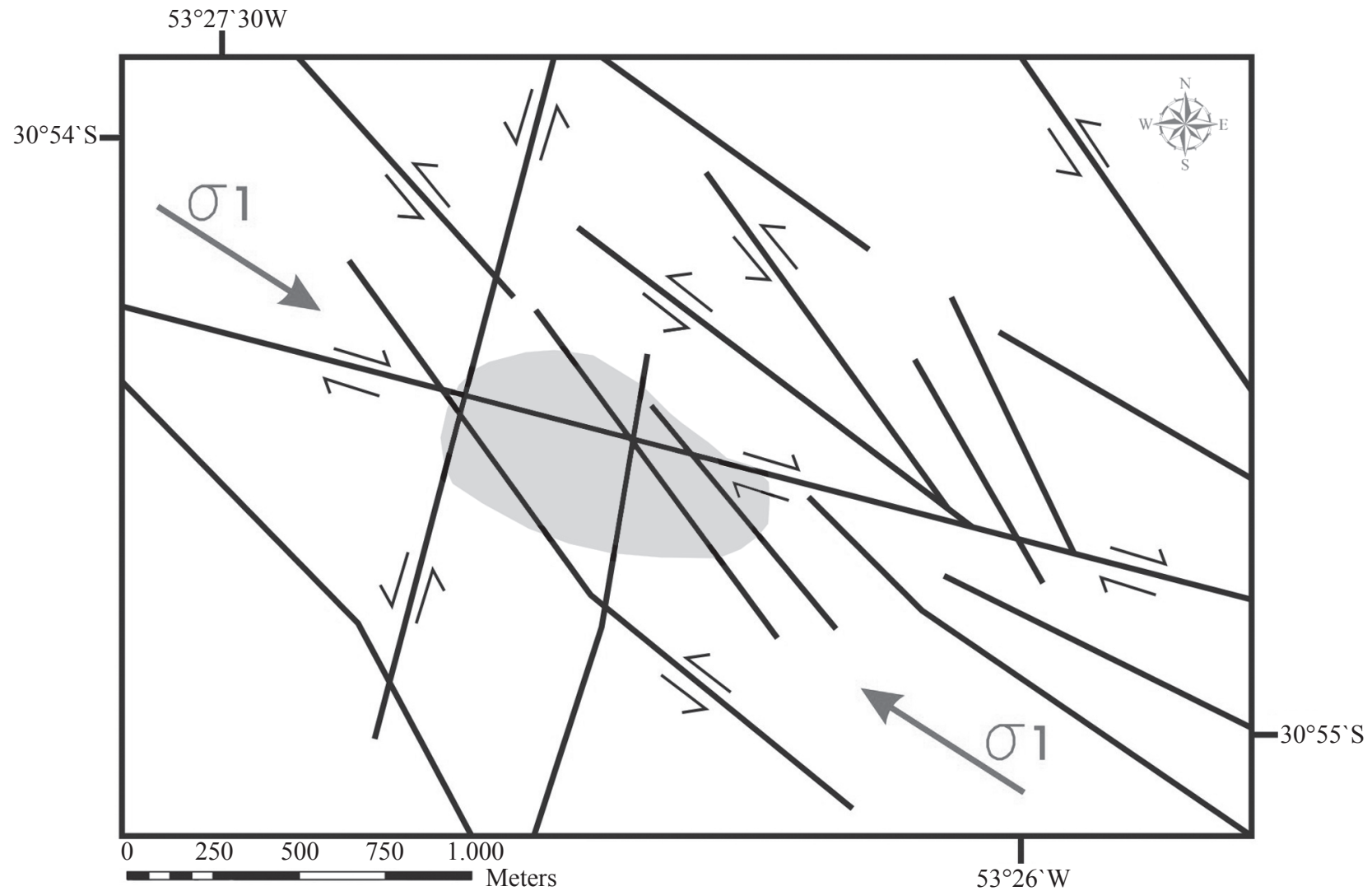

Figure 10 - Representation of the regional kinematics obtained for the main deformation event. Lineaments obtained by remote sensing, kinematic interpreted via structural analysis. The outline of the Uruguay pit appears in gray.

Other slickenside cross-cut relationships indicate the overlap of a stress field related to the $\mathrm{NE}$ extension to another of ENE direction. In the region (Almeida 2005, Tomba 2006), a NE extension is interpreted as being of Cretaceous age, which could be responsible for the two sets of structures through the progression of the deformation and small variations in local stress fields. NNWdirection basic dike identified in the surroundings of the study area suggests that this event may be related to the Eocretaceous magmatism related to the Serra Geral Formation in the region.

The correlation of data obtained by remote sensing with those obtained by structural analysis allowed the interpretation of the regional bloc kinematics during the main deformational event (Fig. 10).

CONCLUSIONS Paleostress analysis enabled the recognition of distinct brittle deformation events. The main deformation event identified in the rocks of the region was characterized as a WNW compression, as previously recognized on a regional scale (Almeida 2005, Almeida et al. 2010), with progressive rotation of the structures by a N-S sinistral transcurrent binary (Santos 2007), which caused the formation and/or the reactivation of dextral E-W direction major structures and sinistral NNE-trend structures.

The mineralized fractures, occasionally related to striated faults, occur in directions that are parallel to the maximum horizontal stress obtained for that event, setting a context of mineralization in a transcurrent system, and related to the opening and filling of fractures which were parallel to the direction of maximum horizontal stress, resembling T-type structures. The event related to the sulphide mineralization occurred after $530 \mathrm{Ma}$, thus being younger than the Guaritas Group.

A NW extension event was identified, which is younger than the WNW compression, and 
older than the N-S compression, probably positioned between the Cambrian and Triassic periods. Another recognized tectonic event was responsible for the formation of structures presenting kinematics which are opposite to the NW extension, and caused by NNE to N-S compression. Strikeslip faults compatible with this stress field are less frequent than those caused by WNW compression. Striae cross-cutting relationships reveal the posteriority of this event in relation to the main deformation, being probably related to brittle deformation with the compatible stress-field that affected Triassic deposits to the east of the study area (Almeida 2005, Tomba 2006). The deformation with predominantly normal faults generated by NE extension is interpreted as of Cretaceous age, as according to those structures previously interpreted by these authors.

ACKNOWLEDGMENTS FAPESP, for the support to projects $06 / 50655-0$ and $05 / 57939-0$, and 10/50902-2. Paulo Mônego is thanked for the access to the study area. Mônica M. Perrotta is thanked for the atmospheric correction processing of the ASTER image. Maria, Taferson and Jonatan (Minas do Camaquã) are thanked for the logistic support.

\section{References}

Almeida F.F.M. 1969. Diferenciação tectônica da Plataforma Brasileira. In: SBG, Congresso Brasileiro de Geologia, 23, Salvador, Anais 1, p.29-46.

Almeida R.P. 2005. Tectônica e Sedimentação do Ediacariano ao Ordoviciano: Exemplos do Supergrupo Camaquã (RS) e do Grupo Caacupé (Paraguai Oriental). Tese de Doutoramento, Instituto de Geociências, Universidade de São Paulo, 203 p.

Almeida R.P., Janikian L., Fragoso-Cesar A.R.S., Fambrini G.L. 2010. The Ediacaran to Cambrian Rift System of Southeastern South America: Tectonic Implications. The Journal of Geology, 118(2):145-161.

Almeida R.P., Janikian L., Fragoso-Cesar A.R.S., Marconato A. 2009. Evolution of a rift basin dominated by subaerial deposits: The Guaritas Rift, Early Cambrian, Southern Brazil. Sedimentary Geology, 217(1-4):30-51.

Almeida R.P., Santos M.G.M., Fragoso-Cesar A.R.S., Janikian L., Fambrini, G.L. (no prelo). Recurring extensional and strike-slip tectonics after the Neoproterozoic collisional events in the southern Mantiqueira province. Anais da Academia Brasileira de Ciências, aceito ainda sem data de publicação.

Angelier J. 1994. Fault slip analysis \& paleostress reconstruction. In: Hancock P.L. (ed.) Continental deformation. Oxford, Pergamon Press, p.53-100.

Angelier, J. \& Mechler, P. 1977. Sur une methode graphique de recherche des contraintes principales egalment utilisable en tectonique et en seismologie: La methode des diedres droits. Bulletin de Societie Geologique de France, v. 19, p. 1309-1318.

Bettencourt J.S. 1972. Geologia da Mina de Camaquã, RS. Tese de Doutoramento, Instituto de Geociências, Universidade de São Paulo, 267 p.

Bettencourt J.S. \& Damasceno E.C. 1974. Análise tectônica e controles de mineralização no distrito cuprífero de Camaquã, RS. In: XXVIII Congresso Brasileiro de Geologia, Porto Alegre, RS. Boletim de
Resumos do XXVIII Congresso Brasileiro de Geologia, 1, p.719-723.

Bott M.H.P. 1959. The mechanics of oblique slip faulting. Geological Magazine, 96(02):109-117.

Carey-Gailhardis E. \& Mercier J.L. 1987. A numerical method for determining the state of stress using focal mechanisms of earthquake populations: application to Tibetan teleseisms and microseismicity of southern Peru. Earth and Planetary Science Letters, 82(1-2): 165-179.

Crósta A.P. 1992. Processamento digital de imagens de sensoriamento remoto. Campinas, Unicamp, 164 pp.

Delvaux D. \& Sperner B. 2003. New aspects of tectonic stress inversion with reference to the TENSOR program. In: Nieuwland D. (ed.) New insights into structural interpretation and modelling. London, Geological Society of London, Special Publication, 212, p.75-100.

Doblas M. 1998. Slickenside kinematic indicators. Tectonophysics, 295(1-2):187-197.

Fambrini G.L. 2003. O Grupo Santa Bárbara (Neoproterozóico III) da Bacia do Camaquã, Rio Grande do Sul. Tese de Doutoramento, Instituto de Geociências, Universidade de São Paulo, 243 p.

Fambrini G.L. 1998. O Grupo Camaquã (Transição Proterozóico-Fanerozóico) na região das Minas doCamaquã, RS: análise estratigráfica de fácies, proveniência e paleocorrentes. Dissertação de Mestrado, Instituto de Geociências, Universidade de São Paulo, 182 p.

Fambrini G.L., Janikian L., Almeida R.P., Fragoso-Cesar A.R.S. 2007. Evolução Estratigráfica e Paleogeográfica do Grupo Santa Bárbara na Sub-bacia Camaquã Central, RS. Geologia USP - Série Cientifica, $7(2): 1-24$.

Fambrini G.L., Janikian L., Almeida R.P., Fragoso-Cesar A.R.S. 2005. O Grupo Santa Bárbara (Neoproterozóico III) na sub-bacia Camaquã Central, RS: sistemas 
deposicionais, paleogeografia e implicações tectônicas, Revista Brasileira de Geociências, 35 (2):227-238.

Fragoso-Cesar A.R.S., Almeida R.P., Fambrini G.L., Pelosi A.P.M.R., Janikian L. 2003. A Bacia Camaquã: um sistema intracontinental anorogênico de rifts do Neoproterozóico III-Eopaleozóico no Rio Grande do Sul. In: SBG, Encontro Estrat. Rio Grande do Sul Escudos e Bacias, 1, Anais, p.139-144.

Fragoso-Cesar A.R.S., Fambrini G.L., Almeida R.P., Pelosi A.P.M.R., Janikian L., Riccomini C., Machado R. 2001. Estruturas induzidas por abalos sísmicos na Formação Santa Bárbara (Neoproterozóico III Eocambriano), Bacia do Camaquã, RS: o exemplo do Passo da Capela. Revista Brasileira de Geociências, 31(2):155-162.

Fragoso-Cesar, A.R.S., Fambrini G.L., Almeida R.P., Pelosi A.P.M.R., Janikian L., Nogueira A.C.R., Riccomini C., Machado R. 2000a. The Neoproterozoic and Eopaleozoic Successions of the Rio Grande do Sul state, southern Brazil: Superposed Basins of the end of the Brazilides Tectonics and the birth of the intracratonic Paraná Basin. In: International Geological Congress, 31, Rio de Janeiro, Brazil, Abstracts (cdrom).

Fragoso-Cesar A.R.S., Fambrini G.L., Almeida R.P., Pelosi A.P.M.R., Janikian L., Riccomini C., Machado R., Nogueira A.C.R., Saes G.S. 2000b. The Camaquã extensional basin: Neoproterozoic to early Cambrian sequences in southernmost Brazil. Revista Brasileira de Geociências, 30(3):442-445.

Petit J.P. 1987. Criteria for the sense of movement on fault surfaces in brittle rocks. Journal of Structural Geology, 9:597-608.

Robertson J.F. 1966. Revision of stratigraphy and nomenclature of rock units in Caçapava Lavras Region. Notas e Estudos, IG-UFRGS, Porto Alegre, 1:41-54.
Ribeiro M.J. 1978. Mapa previsional do cobre no Escudo Sul-Rio-Grandense. Nota explicativa. Série Geologia, n.3 - Seção Geologia Econômica, DNPM Brasília 1, p.1-104.

Ribeiro M.J., Bocchi P.R., Figueiredo Filho P.M., Tessari R.I. 1966. Geologia da quadrícula de Caçapava do Sul, Rio Grande do Sul. Rio de Janeiro, DNPM/DFPM, 232 p.

Santos E.L., Beckel J., Macedo P.M., Gonzales-Filho F., Chaban M. 1978. Divisão lito-estratigráfica do EoCambriano-PréCambriano Superior do Escudo Sul-Riograndense. In: SBG, Congresso Brasileiro de Geologia, 30, Recife, Anais, 2, p.670-684.

Santos M.G.M. 2010. Tectônica e sedimentação na Bacia do Camaquã Central (RS): exemplos do Grupo Garitas e do Grupo Santa Bárbara. Dissertação de Mestrado, Instituto de Geociências, Universidade de São Paulo, 176 p.

Santos M.G.M. 2007. Análise de Paleotensões de Estruturas Rúpteis em Sucessões do Grupo Santa Bárbara (Ediacarano, Bacia do Camaquã) na Mina Uruguai, Minas do Camaquã (RS). Trabalho de Conclusão de Curso, Instituto de Geociências, Universidade de São Paulo, 118 p.

Silva-Filho W.F. 1997. A Formação Guaritas na Porção Centro-Sudeste da Bacia do Camaquã-RS. Dissertação de Mestrado, Instituto de Geociências, Universidade de São Paulo, 121 p.

Tomba C.L.B. 2006. Tectônica e sedimentação das coberturas triássicas isoladas sobre o Alto Estrutural de Rio Grande na região entre Santana da Boa Vista e Canguçu, RS. Trabalho de Conclusão de Curso, Instituto de Geociências, Universidade de São Paulo, 72 p.

Manuscrito ID 16470

Recebido em: 22/12/2009

Aprovado em: 23/04/2012 